Marshall University

Marshall Digital Scholar

Biological Sciences Faculty Research

Biological Sciences

$10-2010$

\title{
Effects of experimental nitrogen additions on plant diversity in an old-growth tropical forest
}

Xiankai Lu

Jiangming Mo

Frank S. Gilliam

Marshall University, gilliam@marshall.edu

Guoyi Zhou

Yunting Fang

Follow this and additional works at: http://mds.marshall.edu/bio_sciences_faculty

Part of the Forest Biology Commons, and the Plant Biology Commons

\section{Recommended Citation}

Lu X, J Mo, FS Gilliam, G Zhou, Y Fang. 2010. Effects of experimental nitrogen deposition on plant diversity in an old-growth tropical forest. Global Change Biology 16:2688-2700.

This Article is brought to you for free and open access by the Biological Sciences at Marshall Digital Scholar. It has been accepted for inclusion in Biological Sciences Faculty Research by an authorized administrator of Marshall Digital Scholar. For more information, please contact zhangj@marshall.edu, martj@marshall.edu. 


\title{
Effects of experimental nitrogen additions on plant diversity in an old-growth tropical forest
}

\author{
XIANKAI LU*, JIANGMING MO*, FRANKS. GILLIAM†, GUOYI ZHOU* and \\ YUNTING FANG* \\ *South China Botanical Garden, The Chinese Academy of Sciences, Dinghu, Zhaoqing, Guangdong 526070, China, †Department of \\ Biological Sciences, Marshall University, Huntington, WV 25755-2510, USA
}

\begin{abstract}
Response of plant biodiversity to increased availability of nitrogen $(\mathrm{N})$ has been investigated in temperate and boreal forests, which are typically N-limited, but little is known in tropical forests. We examined the effects of artificial $\mathrm{N}$ additions on plant diversity (species richness, density and cover) of the understory layer in an $\mathrm{N}$ saturated old-growth tropical forest in southern China to test the following hypothesis: $\mathrm{N}$ additions decrease plant diversity in $\mathrm{N}$ saturated tropical forests primarily from $\mathrm{N}$-mediated changes in soil properties. Experimental additions of $\mathrm{N}$ were administered at the following levels from July 2003 to July 2008: no addition (Control); $50 \mathrm{~kg} \mathrm{Nha}^{-1} \mathrm{yr}^{-1}$ (Low-N); $100 \mathrm{~kg} \mathrm{Nha}^{-1} \mathrm{yr}^{-1}$ (Medium-N), and $150 \mathrm{~kg} \mathrm{Nha}^{-1} \mathrm{yr}^{-1}$ (High-N). Results showed that no understory species exhibited positive growth response to any level of $\mathrm{N}$ addition during the study period. Although low-to-medium levels of $\mathrm{N}$ addition $\left(\leq 100 \mathrm{~kg} \mathrm{Nha}^{-1} \mathrm{yr}^{-1}\right)$ generally did not alter plant diversity through time, high levels of $\mathrm{N}$ addition significantly reduced species diversity. This decrease was most closely related to declines within tree seedling and fern functional groups, as well as to significant increases in soil acidity and $\mathrm{Al}$ mobility, and decreases in $\mathrm{Ca}$ availability and fine-root biomass. This mechanism for loss of biodiversity provides sharp contrast to competitionbased mechanisms suggested in studies of understory communities in other forests. Our results suggest that high-N additions can decrease plant diversity in tropical forests, but that this response may vary with rate of $\mathrm{N}$ addition.
\end{abstract}

Keywords: acidification, aluminum mobility, cation availability, China, functional group, $\mathrm{N}$ deposition, $\mathrm{N}$ saturation, plant diversity, tropical forest, understory layer

Received 31 August 2009; revised version received 10 December 2009 and accepted 11 December 2009

\section{Introduction}

Biodiversity is declining at an unprecedented rate and on a global scale. Indeed, loss of ecosystem functions and services associated with such declines has generated international contention (Sala et al., 2000; Phoenix et al., 2006; Zhou et al., 2006). Several causes have been identified to explain such loss, including increased land use by an expanding human population (Lambin \& Geist, 2006; Reidsma et al., 2006) and global climate change (Thomas et al., 2004; Thuiller, 2007). Human alteration in the global nitrogen $(\mathrm{N})$ cycle has also been identified as a contributor to declines in biodiversity (Gilliam, 2006; Bobbink et al., 2010). Combustion of fossil fuel, production and application of nitrogenous fertilizer, and intensive livestock production have converted considerable amounts of $\mathrm{N}$ from nonreactive $\mathrm{N}_{2}$ to reactive forms $-\mathrm{N}_{\mathrm{r}}$ (e.g., $\mathrm{NH}_{4}^{+}, \mathrm{NO}_{3}^{-}$) (Galloway et al., 2003). Release of $\mathrm{N}_{\mathrm{r}}$ to the atmosphere has resulted in elevated deposition of $\mathrm{N}$ to terrestrial and aquatic

Correspondence: Jiangming Mo, tel. + 86758 2621187, fax +86 758 2623242, e-mail: mojm@scib.ac.cn ecosystems, altering the $\mathrm{N}$ cycle at regional and global scales (Vitousek et al., 1997; Galloway et al., 2003). Excess $\mathrm{N}$ deposition is a potentially serious threat to biodiversity of many groups of organisms, including diversity of plants (Strengbom et al., 2002; Nordin et al., 2006; Clark \& Tilman, 2008), microorganisms (Frey et al., 2004; Carfrae et al., 2006) and animals (Throop \& Lerdau, 2004; $\mathrm{Xu}$ et al., 2006).

Research on the responses of forest plant biodiversity to $\mathrm{N}$ deposition could be traced back to 1970s when European and North American ecologists began to study the effects of $\mathrm{N}$ deposition on the structure and function of temperate forest ecosystems (Dirkse et al., 1991; Högberg et al., 2006). Recent papers have focused on the effects of $\mathrm{N}$ deposition on forest plant biodiversity (see Gilliam, 2006 and Lu et al., 2008 for recent reviews). Response of forest biodiversity to $\mathrm{N}$ deposition is usually one of decline, although some studies have reported no significant change (Hurd et al., 1998; Strengbom et al., 2003; Gilliam et al., 2006; Bobbink et al., 2010). Studying understory vegetation of 557 boreal forest stands along $\mathrm{N}$ deposition gradients throughout Sweden, Strengbom et al. (2003) found that increases in 
$\mathrm{N}$ deposition were significantly correlated with decreases in abundance for the once-dominant species Vaccinium myrtillus. In hardwood forests of USA, Hurd et al. (1998) found that high-N inputs (e.g., $28 \mathrm{~kg} \mathrm{Nha}^{-1} \mathrm{yr}^{-1}$, or four times annual ambient $\mathrm{N}$ deposition) significantly decreased the cover of prominent herbaceous species, Oxalis acetosella, Maianthemum canadense and Huperzia lucidula. By contrast, 6 years of aerial applications of $\mathrm{N}\left(35 \mathrm{~kg} \mathrm{Nha}^{-1} \mathrm{yr}^{-1}\right)$ to a central Appalachian hardwood-dominated watershed had no significant effects on plant diversity (Gilliam et al., 2006). Mechanisms underlying the declines of diversity include competitive exclusion of more $\mathrm{N}$-efficient dominant species by relatively fast-growing nitrophilic species, as a result of high- $\mathrm{N}$ availability induced by N deposition (Gilliam, 2006; Bobbink et al., 2010). Other such mechanisms include increased susceptibility to secondary stress and disturbance factors (e.g., disease and herbivory), and species invasions (Gilliam, 2006; Bobbink et al., 2010). It is notable that our understanding of these mechanisms of plant response to $\mathrm{N}$ deposition comes from temperate/boreal forests and herb-dominated ecosystems, commonly $\mathrm{N}$-limited under natural conditions (e.g., Suding et al., 2005; Gilliam, 2006). To our knowledge, there has been no report to date on the effects of $\mathrm{N}$ deposition on forest plant diversity in tropical or subtropical areas (Lu et al., 2008; Bobbink et al., 2010).

There are several important reasons to address the effects of $\mathrm{N}$ deposition on plants diversity in tropical forest ecosystems. First, tropical forests have the highest biodiversity of all terrestrial ecosystems in the biosphere, providing habitat for over 50\% of the Earth's plant and animal species, and containing $70 \%$ of the world's vascular plants (Wilson, 1988). Second, $\mathrm{N}$ deposition in tropical regions is projected to increase greatly in the coming decades due to the rapid expansion of industrial and agricultural activities (Lamarque et al., 2005; Galloway et al., 2008). Third, tropical forests have a more complex community structure and contain much more dominant tree species almost in all layers than temperate forests (Rosenzweig, 1995; Wiegand et al., 2007). Finally, tropical ecosystems are typically $\mathrm{N}$ rich and phosphorus (P) limited compared with most temperate and boreal ecosystems (Vitousek, 1984; Matson et al., 1999). Fang et al. (2009) found that leaching of dissolved inorganic $\mathrm{N}$ was substantially higher in an old-growth forest of southern China than that of most temperate forests studied in Europe and North America. Sotta et al. (2008) found that, although $\mathrm{N}$ is often in relative excess in old-growth lowland forest soils of Eastern Amazonia, $\mathrm{N}$ availability is greatly influenced by soil texture and, thus, often a function of soil weathering. Indeed, many tropical forest soils are highly weathered, with low base cation concentrations and high Al concentrations (Matson et al., 1999). Therefore, soil-based responses of plant diversity to $\mathrm{N}$ deposition in tropical forests may be different from those in temperate/boreal forests, wherein N-mediated changes in biotic interactions (e.g., competition and herbivory) are often primary mechanisms behind plant diversity response to N (Gilliam, 2006).

In Asia, anthropogenic activities have increased use and emissions of $\mathrm{N}_{\mathrm{r}}$ in from $14 \mathrm{Tg} \mathrm{Nyr}^{-1}$ in 1961 to $68 \mathrm{Tg} \mathrm{Nyr}^{-1}$ in 2000 , and is expected to reach $105 \mathrm{Tg}$ $\mathrm{Nyr}^{-1}$ in 2030 (Zheng et al., 2002). This has lead to rates of wet deposition of $\mathrm{N}\left(\mathrm{NH}_{4}^{+}+\mathrm{NO}_{3}^{-}\right)$in some forests of southern China as high as $30-73 \mathrm{~kg} \mathrm{Nha}^{-1} \mathrm{yr}^{-1}$ (Ma, 1989; Ren et al., 2000; Xu et al., 2001). In old-growth tropical forests of the Dinghushan Biosphere Reserve (DHSBR), $\mathrm{N}$ deposition was $36 \mathrm{~kg} \mathrm{Nha}^{-1} \mathrm{yr}^{-1}$ in 1990 and $38 \mathrm{~kg} \mathrm{Nha}^{-1} \mathrm{yr}^{-1}$ in 1999 (Huang et al., 1994; Zhou \& Yan, 2001), comparable to the highest levels of $\mathrm{N}$ deposition occurring in Europe (MacDonald et al., 2002; Aber et al., 2003), where $\mathrm{N}$ deposition has negatively affected plant diversity (Stevens et al., 2004; Bobbink et al., 2010). It is therefore critical to explore the effects of increasing deposition of $\mathrm{N}$ on plant diversity in these forests of China, especially in southern China where industry has been developed rapidly.

The purpose of this study was to examine effects of artificial $\mathrm{N}$ deposition applications on plant diversity (defined as species richness, density and cover in this study) in an old-growth tropical forest in the DHSBR, one which has been demonstrated to have become $\mathrm{N}$ saturated due to both long-term high-N deposition in the region and its relatively undisturbed state of development (no direct human land use disturbance for more than 400 years) (Mo et al., 2006, 2008b). Work in other tropical forests has shown that inputs of anthropogenic $\mathrm{N}$ deposition in tropical forests may alter other aspects of the $\mathrm{N}$ cycle without time lag, resulting in soil acidification, increased losses of base cations and $\mathrm{Al}$ mobilization, and decreased availability of limiting nutrients, particularly $\mathrm{Ca}^{2+}$ and $\mathrm{Mg}^{2+}$ (Matson et al., 1999). These changes may damage fine roots, alter foliar nutrient balance and inhibit plant growth, or even reduce plant production (Watmough \& Dillon, 2003; Magill et al., 2004), and at last threaten plant biodiversity. It is also proposed that changes of soil properties (e.g., soil acidification, increased base cation leaching and concentrations of potentially toxic metals) induced by high$\mathrm{N}$ deposition may be an important mechanism leading to the declines of diversity (Gilliam, 2006; Wallace et al., 2007; Bobbink et al., 2010). Given the high availability of $\mathrm{N}$ in soils at our study site, we hypothesize the following: $\mathrm{N}$ additions decrease plant diversity in $\mathrm{N}$ saturated tropical forests primarily from $\mathrm{N}$-mediated changes in 
soil properties. Because the understory layer makes an important contribution to plant diversity (Gilliam, 2007), we focus on the diversity of understory layer in this study.

\section{Methods}

\section{Study site}

This study was conducted in the DHSBR, an UNESCO/MAB site located in the middle Guangdong Province in southern China $\left(112^{\circ} 10^{\prime} \mathrm{E}, 23^{\circ} 10^{\prime} \mathrm{N}\right)$ (Fig. 1). The Reserve covers an area of $1155 \mathrm{ha}$, has a monsoon climate, and is located in a subtropical/tropical moist forest life zone (sensu Holdridge, 1967). The Reserve was established in 1950 to protect a remnant of undisturbed natural monsoon evergreen broadleaf forests in the subtropics, and was accepted as the first MAB reserve in China in 1978. The mean annual rainfall of $1927 \mathrm{~mm}$ is distributed seasonally, with $75 \%$ of it falling from March to August; 6\% falls from December to February (Huang \& Fan, 1982). Annual mean relative humidity is $80 \%$. Mean annual temperature is $21.0^{\circ} \mathrm{C}$, with an average coldest (January) and warmest (July) temperature of 12.6 and $28.0^{\circ} \mathrm{C}$, respectively. Nitrogen deposition (inorganic $\mathrm{N}$ in precipitation) measured in 2004 and 2005 was 34 and $32 \mathrm{~kg} \mathrm{Nha}^{-1} \mathrm{yr}^{-1}$, respectively, $60 \%$ of which was in the form of $\mathrm{NH}_{4}^{+}-\mathrm{N}$ (Fang et al., 2008).

We established our research site in monsoon evergreen broadleaf forest in 2002 at elevations between 250 and $300 \mathrm{~m}$ above sea level. The forest has been protected from direct human land use disturbance for more than 400 years, according to ${ }^{14} \mathrm{C}$ measurement (Shen et al., 1999), and contains a complex variety of plant species (Cao et al., 2002). The aboveground community can be divided into five layers: three arbor (tree) layers, one shrub layer, and one grass layer. Shrub and grass layers of these forests are commonly considered the understory layer. In addition, the aboveground community has many kinds of interlayer plants (liana and epiphytes). Predominant species in the canopy and subcanopy layers are evergreen tree plants, most of which are often natives of the tropics and subtropics, including Castanopsis chinensis Hance, Schima superba Chardn. \& Champ., Cryptocarya chinensis (Hance) Hemsl., Cryptocarya concinna Hance, Machilus chinensis (Champ. Ex Benth.) Hemsl., and Syzygium rehderianum Merr. \& Perry. Canopy closure is typically above $95 \%$. Plant diversity in the understory layer is very high and most of the species diversity of the forests occurs in this layer, including tree seedlings, woody vines, shrubs, and herbaceous plants (Appendix S1). The soil in the study site is lateritic red earth (oxisols) formed from sandstone with a soil depth $>60 \mathrm{~cm}$ (Mo et al., 2003).

\section{Experimental treatments}

Nitrogen-addition experiments were initiated in July 2003 (Mo et al., 2006). Four N-addition treatments (in three replicates) were established: Control (without $\mathrm{N}$ added), Low-N $\left(50 \mathrm{~kg} \mathrm{Nha}^{-1} \mathrm{yr}^{-1}\right), \quad$ Medium-N $\quad\left(100 \mathrm{~kg} \mathrm{Nha}^{-1} \mathrm{yr}^{-1}\right)$, and High-N $\left(150 \mathrm{~kg} \mathrm{Nha}^{-1} \mathrm{yr}^{-1}\right)$. Twelve $20 \mathrm{~m} \times 10 \mathrm{~m}$ plots were established with each plot surrounded by a $10 \mathrm{~m}$ wide buffer strip. All plots and treatments were laid out randomly. In addition, two $1 \mathrm{~m} \times 1 \mathrm{~m}$ subplots were permanently established in each plot, for a total of 24 subplots. Monthly applications of $\mathrm{NH}_{4} \mathrm{NO}_{3}$ solution were administered by hand to the

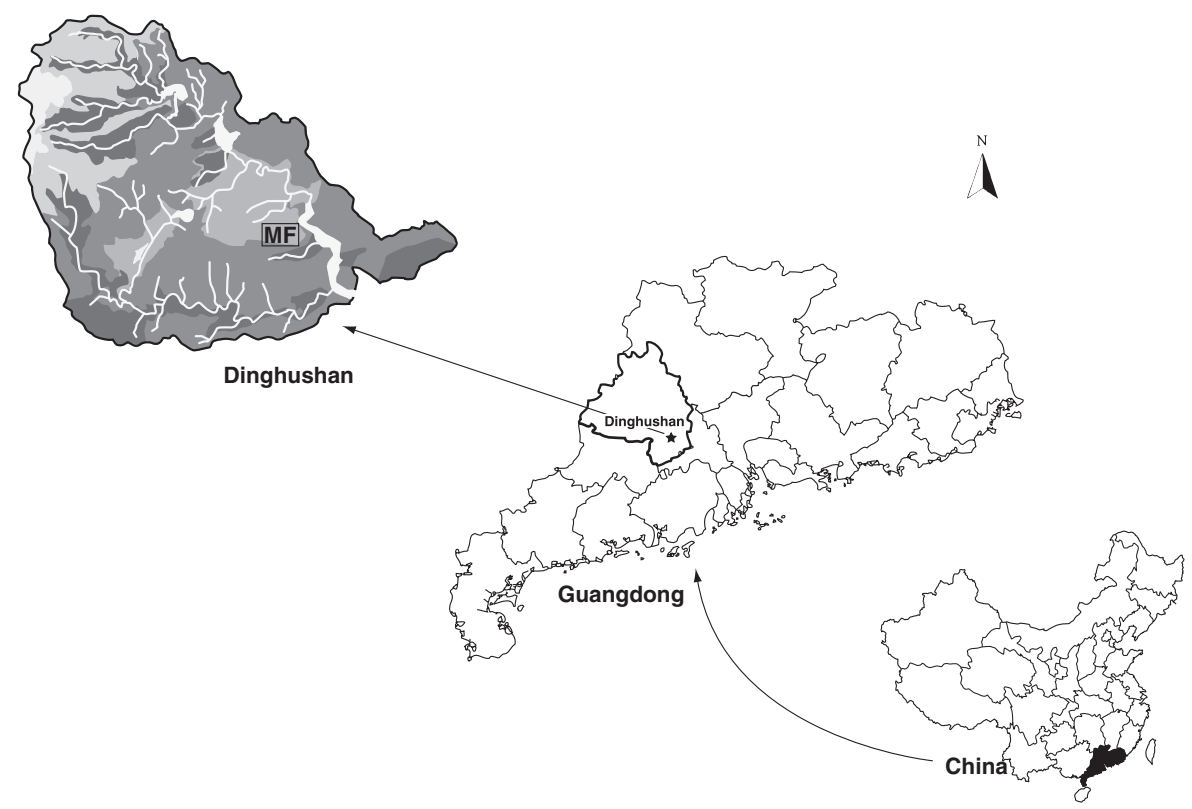

Fig. 1 Map of China with the other Provinces indicated by lines and with Guangdong Province shaded in black. Guangdong Province is expanded with Dinghushan Biosphere Reserve is marked with asterisk. Dinghushan Biosphere Reserve is also expanded, and shows the location of the old-growth monsoon evergreen broadleaf forest (MF, mature forest). 
forest floor of these plots as 12 equal applications over the whole year. During each application, fertilizer was weighed, mixed with $20 \mathrm{~L}$ of water, and applied to each of the $20 \mathrm{~m} \times 10 \mathrm{~m}$ plots using a backpack sprayer below the canopy. Two passes were made across each plot to ensure an even distribution of fertilizer. Control plots received $20 \mathrm{~L}$ of deionized water.

\section{Field sampling}

The understory layer, defined here as all vascular plants $\leq 1 \mathrm{~m}$ in height (similar to the herbaceous layer sensu Gilliam \& Roberts, 2003), was monitored within the two permanent $1 \mathrm{~m}^{2}$ subplots in each plot. We chose this layer and definition because (1) it is widely used in the literature, (2) this stratum is sensitive to changes in nutrient availability, and (3) most of the plant biodiversity of forests is typically found there (see Gilliam, 2007 for a review). For the sake of including all plants tallied during the pretreatment sampling, any individual plants within this stratum that eventually grew above $1 \mathrm{~m}$ in height were included in further sampling and analysis. We performed a field survey of each subplot in July every year, and recorded all the vascular plants in the understory layer. The cover (percentage) of the individual plant species was estimated visually using a square grid method. Field tests were carried out to check the between-observer assessment level, and to calibrate it when necessary.

To explore possible mechanisms for changes of understory in diversity, we carried out two-time collections of soil samples in September 2004 and 2005, respectively, for determining soil $\mathrm{pH}$, inorganic $\mathrm{N}\left(\mathrm{NH}_{4}^{+}-\mathrm{N}\right.$ and $\left.\mathrm{NO}_{3}^{-}-\mathrm{N}\right)$, and extractable soil $\mathrm{Ca}$ and $\mathrm{Al}(\mathrm{Lu}$ et al., 2009). Soil inorganic $\mathrm{N}$ was extracted with $2 \mathrm{~mol} \mathrm{~L}^{-1} \mathrm{KCl}$. Exchangeable Ca was extracted with $1 \mathrm{~mol} \mathrm{~L}^{-1}$ $\mathrm{NH}_{4} \mathrm{OAc}$ and exchangeable $\mathrm{Al}$ was extracted with $1 \mathrm{~mol} \mathrm{~L}^{-1}$ $\mathrm{KCl}$ (10:1, solution: soil). We determined fine root biomass (diameter $\leq 2 \mathrm{~mm}$ ) in September 2005 (Mo et al., 2008b). In addition, we also used Plant Canopy Analyzer LAI-2000 (LICOR Inc., Lincoln, NE, USA) to estimate tree canopy closure in August 2008 (Machado \& Reich, 1999; Li et al., 2008).

\section{Data analysis}

All understory plants were classified into one of five functional groups on the basis of intrinsic morphological differences: (1) tree seedlings (height $\leq 1 \mathrm{~m}$, not including germinated seedlings of current year), (2) woody vines (height $\leq 1 \mathrm{~m}$ ), (3) shrubs (height $\leq 1 \mathrm{~m}$ ), (4) herbaceous plants, and (5) ferns. Although ferns are usually grouped with herbaceous plants in studies of the understory layer, we distinguish the two groups in our study because of differences in reproduction (nonflowering vs. flowering) and because of the demonstrated differences in how ferns can alter competitive outcomes in forest herb communities (George \& Bazzaz, 2003). To simultaneously test for overall $\mathrm{N}$ treatment effects over time for the study period from 2003 to 2008 , we subjected data to two way repeated-measures analysis of variance (ANOVA) with Tukey's honestly significantly different (HSD) test (using STATISTIX 9, ANALYTICAL SOFTWARE 2008) on the following variables: density (mean number of plants $\mathrm{m}^{-2}$ in each replication), cover (mean percent cover of plants in each replication) and richness (mean number of species $\mathrm{m}^{-2}$ in each replication). One-way ANOVA with Tukey's HSD test was performed to test the differences of the above variables among treatments for the same year and among years for the same treatment. We also conducted the planned contrast analysis to test the differences between Control plots against the N-treatment plots. Relative measures of richness, density, and cover were calculated as the plot average for the specified period divided by the average diversity of species in the Control in that field over the same period. The proportional loss/gain of species relative to Control was calculated using the method of Clark \& Tilman (2008): one minus the ratio of relative species diversity. In addition, we used a general linear model to analyze the relationships between density and richness, cover and richness, and cover and density in all plots in 2008. For fine root biomass, soil chemical properties (soil $\mathrm{pH}$, inorganic $\mathrm{N}$, and extractable $\mathrm{Al}$ and $\mathrm{Ca}$ ) and canopy closure, one-way ANOVA with Tukey's HSD test was also performed to test the differences among treatments. One-way ANOVA, planned contrast analysis and linear analyses were conducted using SPSS 14.0 for Windows ${ }^{\circledR}$ (SPSS, Chicago, IL, USA). Statistically significant differences were set at $P<0.05$ unless otherwise stated.

\section{Results}

Sampling within our subplots captured a total of 48 plant species belonging to five functional groups (i.e., tree seedlings, woody vines, shrubs, herbaceous plants, and ferns, Appendix S1). Before treatments in 2003, the understory vegetation of the experimental site was homogeneous and there were no significant $(P>0.05$, Tukey's HSD test) differences between the Control and $\mathrm{N}$ treatment plots for any measured variables (richness, density and cover). Among the five functional groups, tree seedlings were dominant in terms of species richness, density, and cover, making up a major proportion (about $50 \%$ ) of total plant diversity in all plots in the first year. Of the total of 107 individual tree seedlings tallied in our study, only four grew higher than $1 \mathrm{~m}$ $(1.05,1.05,1.1$, and $1.2 \mathrm{~m}$, respectively) in 2008. Furthermore, there were no significant differences among $\mathrm{N}$ treatments in mean overstory cover over the course of the study (Fig. 2).

\section{Response of total plant diversity to $\mathrm{N}$ additions}

Repeated measures ANOVA showed significant effects of $\mathrm{N}$ treatment and time on total plant richness, density and cover, and significant interaction between treatment and time for cover and richness (Table 1A-C). Although none of the $\mathrm{N}$ treatments significantly altered plant richness and density in 2003-2004, the High-N treatment significantly decreased these relative to the Control beginning 


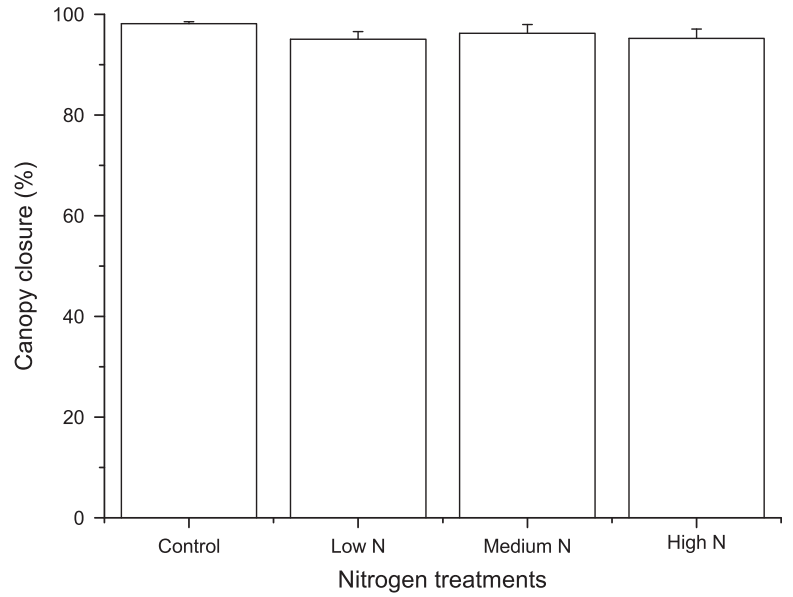

Fig. 2 Mean canopy closure for the forest overstory for all $\mathrm{N}$ treatments: control, low $\mathrm{N}$, medium $\mathrm{N}$, and high $\mathrm{N}$. Means were not significantly different among $\mathrm{N}$ treatments by Tukey's honestly significantly different test (Tukey's HSD test). Bars indicate \pm SE.

in 2005. A similar response occurred for plant cover beginning in 2006. $\mathrm{N}$-treatment effects on plant richness, density, and cover became significant in Low-N plots in 2008, compared with the Control (Fig. 3a-c). During the study period from 2003 to 2008, plant richness, density, and cover showed minor variations between years in the Control and Low-N plots, but decreased slightly with time in the Medium-N plots (Fig. 3a-c). This decreasing trend was more pronounced in the High-N plots, where plant richness, density, and cover decreased significantly with time ( $P=0.008,0.03$, and 0.055 , respectively). In the high-N treatment, plant richness significantly decreased after $2004(P=0.043)$, as did plant density from 2006 $(P=0.043)$, compared with 2003. Plant richness, density, and cover all decreased by approximately $74 \%$ from 2003 to 2008 following 5 years of treatment in the High-N plots (Fig. 3a-c). In general, N-addition treatments significantly decreased total plant diversity with years, and this response pattern was mainly due to the response of tree seedling group because of its dominance in understory.

Relative measures of all plant diversity parameters showed a slightly increased trend (e.g., about $22 \%$ per year for richness compared with 2003) in the first 4 years in the Low-N plots, and then decreased in 2008, especially for plant cover, which decreased by around $54 \%$ relative to that of the Control plots (Fig. $3 \mathrm{~d}-\mathrm{f}$ ). These parameters decreased greatly with time in the Medium-N and High-N plots (Fig. 3d-f). After 5 years of continuous $\mathrm{N}$ additions, plant richness, density, and cover decreased by $\sim 50 \%$ in the Medium-N plots relative to the Controls. In the High-N plots, plant richness, density, and cover decreased approximately by $80 \%$ relative to Controls.
Table 1 Results of repeated measures analysis of variance for understory layer species richness, density and cover for Dinghushan Forest, 2003-2008

\begin{tabular}{|c|c|c|c|c|c|}
\hline Source & $\mathrm{DF}$ & SS & MS & $F$ & $P$ \\
\hline \multicolumn{6}{|l|}{ (A) Richness (species $/ m^{2}$ ) } \\
\hline Treatment & 3 & 124.6 & 41.5 & 5.71 & 0.023 \\
\hline $\begin{array}{l}\text { Error: treatment } \times \\
\text { replication }\end{array}$ & 8 & 58.2 & 7.3 & & \\
\hline Year & 5 & 19.4 & 3.9 & 3.97 & 0.005 \\
\hline Treatment $\times$ year & 15 & 57.0 & 3.8 & 3.90 & 0.000 \\
\hline $\begin{array}{l}\text { Error: treatment } \times \\
\text { replication } \times \text { year }\end{array}$ & 40 & 39.0 & 1.0 & & \\
\hline Total & 71 & & & & \\
\hline \multicolumn{6}{|l|}{ (B) Density (stems $/ m^{2}$ ) } \\
\hline Treatment & 3 & 426.7 & 142.2 & 6.61 & 0.015 \\
\hline $\begin{array}{l}\text { Error: treatment } \times \\
\text { replication }\end{array}$ & 8 & 172.2 & 21.5 & & \\
\hline Year & 5 & 42.1 & 8.4 & 2.56 & 0.042 \\
\hline Treatment $\times$ year & 15 & 80.4 & 5.4 & 1.63 & 0.108 \\
\hline $\begin{array}{l}\text { Error: treatment } \times \\
\text { replication } \times \text { year }\end{array}$ & 40 & 131.3 & 3.3 & & \\
\hline Total & 71 & & & & \\
\hline \multicolumn{6}{|l|}{ (C) Cover (\%) } \\
\hline Treatment & 3 & 9598.7 & 3199.6 & 7.22 & 0.012 \\
\hline $\begin{array}{l}\text { Error: treatment } \times \\
\text { replication }\end{array}$ & 8 & 3543.9 & 443.0 & & \\
\hline Year & 5 & 804.9 & 160.8 & 3.01 & 0.021 \\
\hline Treatment $\times$ year & 15 & 1970.1 & 131.3 & 1.46 & 0.012 \\
\hline $\begin{array}{l}\text { Error: treatment } \times \\
\text { replication } \times \text { year }\end{array}$ & 40 & 2137.0 & 53.4 & & \\
\hline Total & 71 & & & & \\
\hline
\end{tabular}

Significant sources of variation indicated in bold font.

In addition, when compared across all plots and treatments, both plant density and cover were significantly and positively correlated with species richness $\left(r^{2}=0.97, P<0.0001\right.$, and $r^{2}=0.86, P<0.0001$, respectively). Also, plant cover was significantly correlated with density $\left(r^{2}=0.86, P<0.0001\right.$; Fig. 4$)$.

\section{Response of diversity within functional groups to $N$ additions}

During the study period, tree seedling diversity decreased with time in all $\mathrm{N}$ treatment plots, especially in High-N treatment plots, where tree seedling richness, density and cover decreased significantly since 2005 (Fig. 5a-c; Table 2). Repeated measures ANOVA also showed significant effects of $\mathrm{N}$ treatment and time on tree seedling diversity, but the interactions between treatment and time were not significant for them (data not shown). In High-N treatment plots, tree seedling richness, density, and cover decreased by $88 \%, 90 \%$, and $76 \%$, respectively, from 2003 to 2008 following 5 years of 

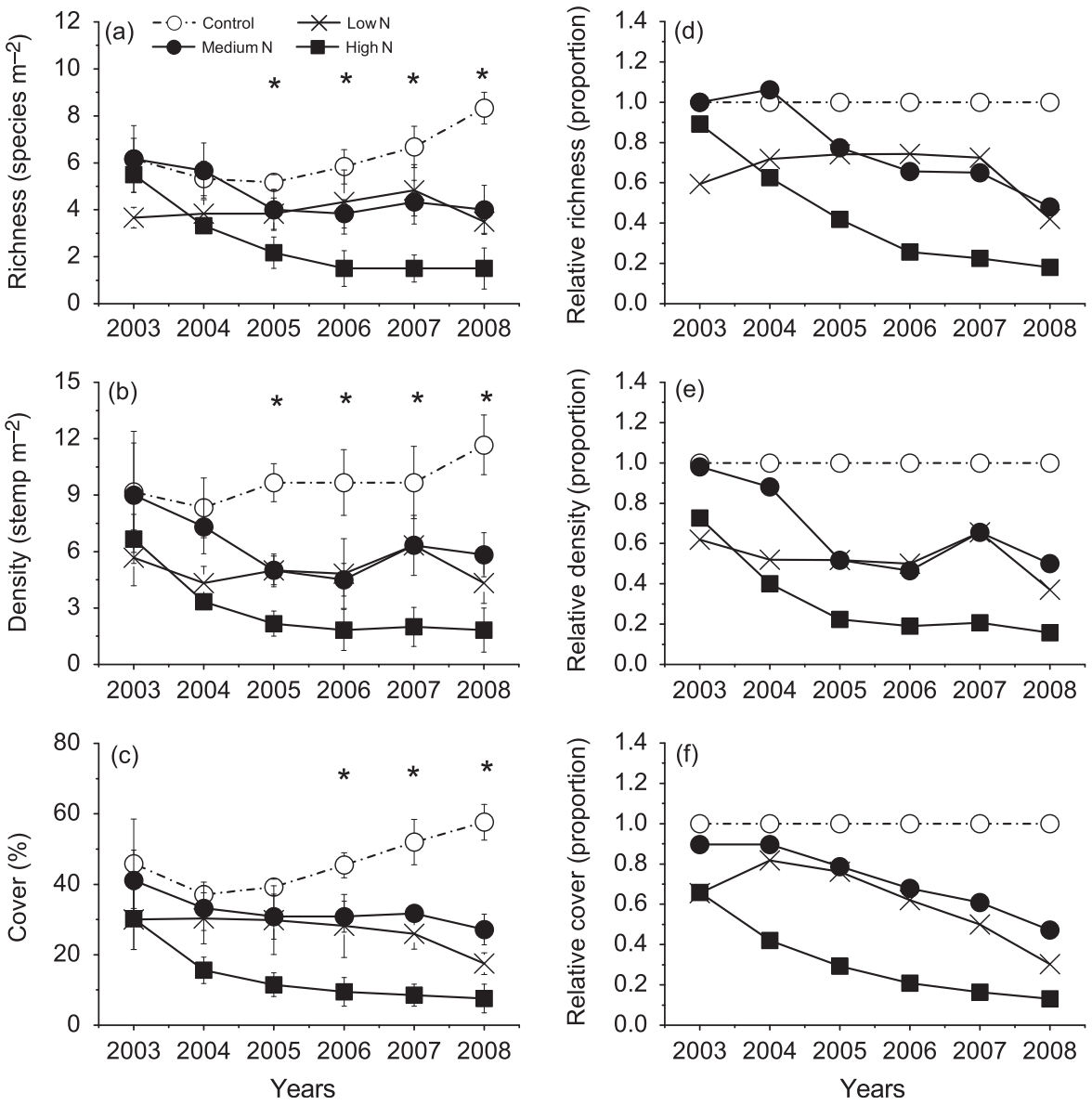

Fig. 3 Temporal patterns of responses of plant diversity (a, richness; b, density; and c, cover), and their relative diversity (d, richness; e, density; and $\mathrm{f}$, cover) to $\mathrm{N}$ treatment levels in understory layers for years 2003-2008. Bars indicate \pm SE. Notes: open circles, Control; furcations, Low-N treatment; solid circles, Medium-N treatment; solid square, High-N treatment. *Significant difference between Control plots against $\mathrm{N}$-treatment plots at $P<0.05$ using planned contrast analysis.

treatment. Relative measures of tree seedling diversity parameters also showed decreased trends with years in all $\mathrm{N}$ treatment plots (Fig. $5 \mathrm{~d}-\mathrm{f}$ ). After 5 years of continuous $\mathrm{N}$ additions, tree seedling richness, density, and cover decreased by $40 \%-55 \%$ in the Medium-N plots relative to the Controls. In the High-N plots, these parameters decreased by $80 \%-90 \%$ relative to Controls.

In the tree seedling group, seedlings of Machilus chinensis, Crypwcorya concinna, Randia canthioides were dominant, based on average relative abundance over the entire experimental period. Density of dominant and nondominant species showed decreasing trends in Medium-N and High-N plots; density of nondominant species also decreased in Low-N plots.

$\mathrm{N}$-treatment effects were not significant on other functional groups (e.g., woody vines, shrubs, herbaceous plants, and ferns) (Table 2). In addition, only density of fern groups decreased greatly with time, especially in High-N plots $(P<0.001)$. Repeated mea- sures analysis also showed the significant time effects for fern groups $(F=4.78, P=0.017)$.

Responses of soil properties and fine root biomass to $\mathrm{N}$ additions

In September 2004, there were no significant $(P>0.05)$ differences for soil properties (soil $\mathrm{pH}$, inorganic $\mathrm{N}$, and extractable $\mathrm{Al}$ and $\mathrm{Ca}$ ) among treatment plots. Soil $\mathrm{pH}$ and extractable $\mathrm{Ca}$ showed a slight decreasing trend with elevated $\mathrm{N}$ treatment levels. Soil $\mathrm{pH}$ was $3.92 \pm 0.03$ ( \pm 1 standard error of mean, and hereafter), $3.80 \pm 0.08,3.78 \pm 0.01$ and $3.78 \pm 0.01$ in Control, Low$\mathrm{N}$, Medium-N, and High-N plots, respectively; and the contents of soil extractable Ca were $380 \pm 55,351 \pm 16$, $343 \pm 38$, and $347 \pm 33 \mathrm{mg} \mathrm{kg}^{-1}$ in these treatment plots, respectively. Soil extractable $\mathrm{Al}$ showed a slight increasing trend with elevated $\mathrm{N}$ treatment levels, and the contents were $407 \pm 24,433 \pm 28,457 \pm 19$, and 

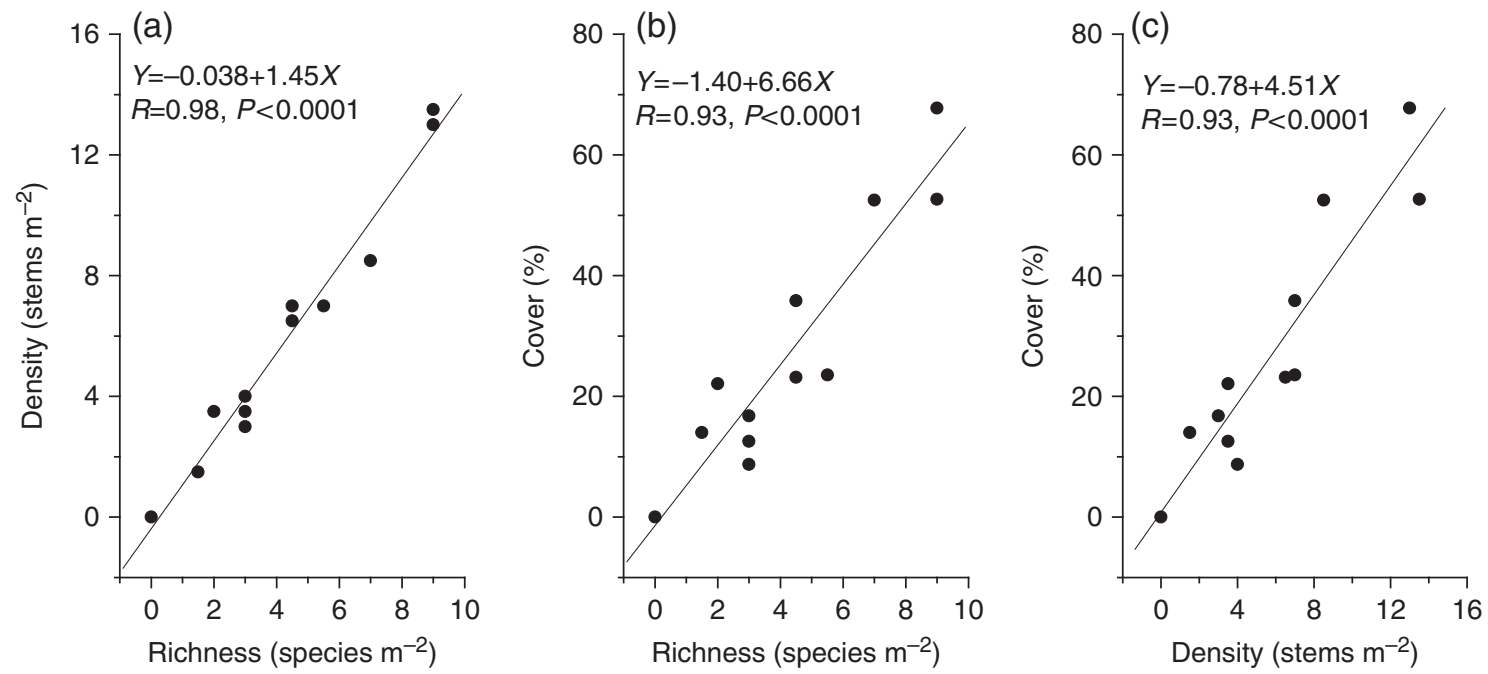

Fig. 4 Relationships between density and richness (a), cover and richness (b) and cover and density (c) in all plots of understory layers in 2008 at Dinghushan Forest. Each point represents a replication for four $\mathrm{N}$ treatment levels.
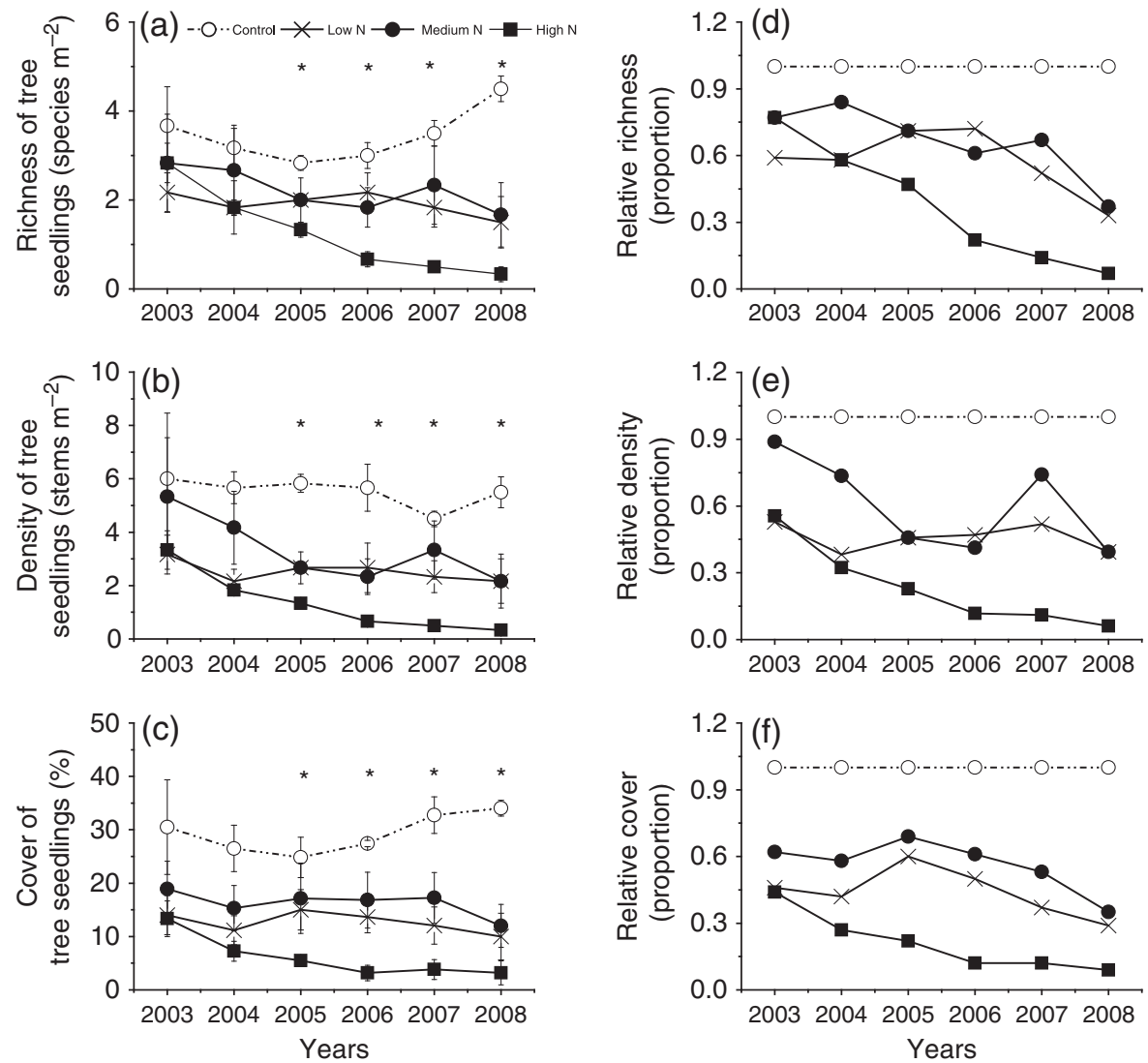

Fig. 5 Temporal patterns of responses of tree seedling diversity ( $a$, richness; b, density; and c, cover), and their relative diversity (d, richness; e, density; and f, cover) to $\mathrm{N}$ treatment levels in understory layers for years 2003-2008. Bars indicate \pm SE. Notes: open circles, Control; furcations, Low-N treatment; solid circles, Medium-N treatment; solid square, High-N treatment. *Significant difference between Control plots against $\mathrm{N}$-treatment plots at $P<0.05$ using planned contrast analysis. 
Table 2 Density $\left(\right.$ stems $/ \mathrm{m}^{2}$ ) responses of five functional groups to experimental additions of $\mathrm{N}$ with years

\begin{tabular}{|c|c|c|c|c|c|c|c|}
\hline \multirow[b]{2}{*}{ Functional groups } & \multirow[b]{2}{*}{ Treatments } & \multicolumn{6}{|l|}{ Years } \\
\hline & & 2003 & 2004 & 2005 & 2006 & 2007 & 2008 \\
\hline \multirow[t]{4}{*}{ Tree seedlings } & Control & $6.00(2.47) \mathrm{Aa}$ & $5.67(0.60) \mathrm{Aa}$ & $5.83(0.33) \mathrm{Aa}$ & $5.67(0.88) \mathrm{Aa}$ & $4.50(0.29) \mathrm{Aa}$ & $5.50(0.58) \mathrm{Aa}$ \\
\hline & Low $\mathrm{N}$ & 3.17 (0.73)Aa & 2.17 (0.44)Aab & $2.67(0.17) \mathrm{Ab}$ & 2.67 (0.93)Aab & $2.33(0.60) \mathrm{Aab}$ & $2.17(0.83) \mathrm{Ab}$ \\
\hline & Medium N & $5.33(2.20) \mathrm{Aa}$ & 4.17 (1.36)Aab & $2.67(0.60) \mathrm{Ab}$ & $2.33(0.67) \mathrm{Ab}$ & 3.33 (1.09)Aab & $2.17(1.01) \mathrm{Ab}$ \\
\hline & High N & 3.33 (0.73)Aa & $1.83(0.17) \mathrm{ABb}$ & $1.33(0.17) \mathrm{Bb}$ & $0.67(0.17) \mathrm{Bb}$ & $0.50(0.00) \mathrm{Bb}$ & $0.33(0.17) \mathrm{Bb}$ \\
\hline \multirow[t]{4}{*}{ Woody vines } & Control & $1.50(0.58) \mathrm{ABa}$ & $0.83(0.17) \mathrm{Ba}$ & $1.50(0.29) \mathrm{ABa}$ & $1.33(0.44) \mathrm{ABa}$ & $2.33(0.17) \mathrm{ABa}$ & $3.33(0.67) \mathrm{Aa}$ \\
\hline & Low $\mathrm{N}$ & $1.00(0.50) \mathrm{ABa}$ & $0.67(0.44) \mathrm{Ba}$ & $0.83(0.17) \mathrm{Ba}$ & $0.67(0.17) \mathrm{Ba}$ & $2.67(0.60) \mathrm{Aa}$ & $0.83(0.17) \mathrm{ABb}$ \\
\hline & Medium N & $1.33(0.44) \mathrm{Aa}$ & $1.00(0.50) \mathrm{Aa}$ & 1.17 (0.33)Aa & $1.00(0.29) \mathrm{Aa}$ & $2.00(0.87) \mathrm{Aa}$ & $2.17(0.33) \mathrm{Aa}$ \\
\hline & High N & $0.83(0.17) \mathrm{Aa}$ & $0.50(0.50) \mathrm{Aa}$ & $0.33(0.33) \mathrm{Aa}$ & $0.67(0.67) \mathrm{Aa}$ & $0.83(0.60) \mathrm{Aa}$ & $0.67(0.44) \mathrm{Ab}$ \\
\hline \multirow[t]{4}{*}{ Shrubs } & Control & $0.67(0.44) \mathrm{Aa}$ & $0.67(0.33) \mathrm{Aa}$ & $0.50(0.29) \mathrm{Aa}$ & $0.50(0.29) \mathrm{Aa}$ & $0.33(0.17) \mathrm{Aa}$ & $0.67(0.44) \mathrm{Aa}$ \\
\hline & Low $\mathrm{N}$ & $0.67(0.44) \mathrm{Aa}$ & $0.67(0.44) \mathrm{Aa}$ & $0.50(0.29) \mathrm{Aa}$ & $0.50(0.29) \mathrm{Aa}$ & 0.17 (0.17)Aa & 0.33 (0.17)Aa \\
\hline & Medium N & $0.67(0.44) \mathrm{Aa}$ & $0.67(0.44) \mathrm{Aa}$ & $0.33(0.17) \mathrm{Aa}$ & $0.50(0.29) \mathrm{Aa}$ & $0.33(0.17) \mathrm{Aa}$ & 0.67 (0.17)Aa \\
\hline & High N & $0.33(0.17) \mathrm{Aa}$ & 0.17 (0.17)Aa & $0.17(0.17) \mathrm{Aa}$ & $0.33(0.33) \mathrm{Aa}$ & $0.50(0.50) \mathrm{Aa}$ & $0.67(0.67) \mathrm{Aa}$ \\
\hline \multirow[t]{4}{*}{ Herbaceous plants } & Control & 0.17 (0.17)Aa & 0.17 (0.17)Aa & $0.67(0.33) \mathrm{Aa}$ & 0.67 (0.17)Aa & $1.33(0.88) \mathrm{Aa}$ & $1.00(0.58) \mathrm{Aa}$ \\
\hline & Low $\mathrm{N}$ & $0.33(0.33) \mathrm{Aa}$ & 0.17 (0.17)Aa & $0.33(0.33) \mathrm{Aa}$ & 0.17 (0.17)Aa & 0.17 (0.17)Aa & 0.17 (0.17)Aa \\
\hline & Medium N & 0.67 (0.33)Aa & $0.67(0.33) \mathrm{Aa}$ & $0.33(0.17) \mathrm{Aa}$ & $0.33(0.17) \mathrm{Aa}$ & 0.17 (0.17)Aa & $0.50(0.50) \mathrm{Aa}$ \\
\hline & High N & 0.17 (0.17)Aa & $0.33(0.33) \mathrm{Aa}$ & 0.17 (0.17)Aa & 0.17 (0.17)Aa & 0.17 (0.17)Aa & 0.17 (0.17)Aa \\
\hline \multirow[t]{4}{*}{ Ferns } & Control & $0.83(0.44) \mathrm{Aa}$ & $1.00(0.76) \mathrm{Aa}$ & 1.17 (0.73)Aa & $1.50(1.04) \mathrm{Aa}$ & $1.17(0.60) \mathrm{Aa}$ & 1.17 (0.93)Aa \\
\hline & Low $\mathrm{N}$ & $0.50(0.50) \mathrm{Aa}$ & $0.67(0.44) \mathrm{Aa}$ & $0.67(0.44) \mathrm{Aa}$ & $0.83(0.60) \mathrm{Aa}$ & $1.00(0.76) \mathrm{Aa}$ & $0.83(0.60) \mathrm{Aa}$ \\
\hline & Medium N & $1.00(0.29) \mathrm{Aa}$ & $0.83(0.33) \mathrm{Aa}$ & $0.50(0.29) \mathrm{Aa}$ & $0.33(0.17) \mathrm{Aa}$ & $0.50(0.29) \mathrm{Aa}$ & 0.33 (0.17)Aa \\
\hline & High N & $2.00(0.29) \mathrm{Aa}$ & $0.50(0.29) \mathrm{Ba}$ & $0.17(0.17) \mathrm{Ba}$ & $0.00(0.00) \mathrm{Ba}$ & $0.00(0.00) \mathrm{Ba}$ & $0.00(0.00) \mathrm{Ba}$ \\
\hline
\end{tabular}

The different capital letters indicate significant differences at $P<0.05$ level among years for the same treatment, and the different lowercase letters indicate significant differences at $P<0.05$ level among $\mathrm{N}$ treatment levels for the same year (Tukey's HSD test). Values are mean with SE in parentheses.

$465 \pm 18 \mathrm{mg} \mathrm{kg}^{-1}$ in Control, Low-N, Medium-N, and High-N plots, respectively.

In September 2005, there were significant responses of these soil properties and fine root biomass to the High-N treatment. Total inorganic $\mathrm{N}$ (sum of $\mathrm{NH}_{4}^{+}-\mathrm{N}$ and $\left.\mathrm{NO}_{3}^{-}-\mathrm{N}\right)$ increased significantly $(P<0.05)$ in response to $\mathrm{N}$ treatment and $\mathrm{NO}_{3}^{-}-\mathrm{N}$ accounted for $80 \%-90 \%$ of total inorganic $\mathrm{N}$ for all treatments (Fig. 6a). Soil pH and extractable Ca decreased greatly with increasing level of $\mathrm{N}$ additions, and the difference between the Control and High-N plots was significant $(P<0.05)$ (Fig. $6 \mathrm{~b}$ and $\mathrm{c})$. Extractable soil $\mathrm{Al}$, however, exhibited opposite pattern in response to $\mathrm{N}$ additions, with high-N additions significantly increasing extractable soil Al concentrations (Fig. 6d). In addition, biomass of fine roots decreased significantly with increasing levels of $\mathrm{N}$ addition (Fig. 6e).

\section{Discussion}

We have demonstrated that $\mathrm{N}$ additions decreased understory plant diversity of an old-growth tropical forest, especially at the highest level of $\mathrm{N}$ additions, a result consistent with many reported for temperate and boreal forests (Hurd et al., 1998; Rainey et al., 1999;
Strengbom et al., 2002; Gilliam, 2006). On the other hand, there are notable differences between our forests and those of temperate and boreal regions regarding the response to $\mathrm{N}$ additions for plant diversity. We found that $\mathrm{N}$-mediated declines in understory diversity were more related to the reductions of plant species in tree seedling and fern functional groups (Table 2). This contrasts sharply with studies in temperate and boreal forests which have shown that forest diversity responses to $\mathrm{N}$ deposition were primarily a function of changes in forb and grass species (Brunet et al., 1998; van Dobben et al., 1999). Such a difference is especially pronounced in the low prevalence of ferns, which can be highly sensitive to $\mathrm{N}$ inputs, in altering the outcome of competitive interactions in the understory layer of our study site compared with other forest types wherein ferns species play a prominent role (George \& Bazzaz, 2003; Coomes et al., 2005).

In temperate and boreal forest ecosystems, which are commonly N limited (Vitousek \& Howarth, 1991), belowground competition for $\mathrm{N}$ nutrient can be intense; thus, availability of $\mathrm{N}$ is an important factor determining species composition of vegetation. Also, most plant species from such habitats are adapted to low-N con- 

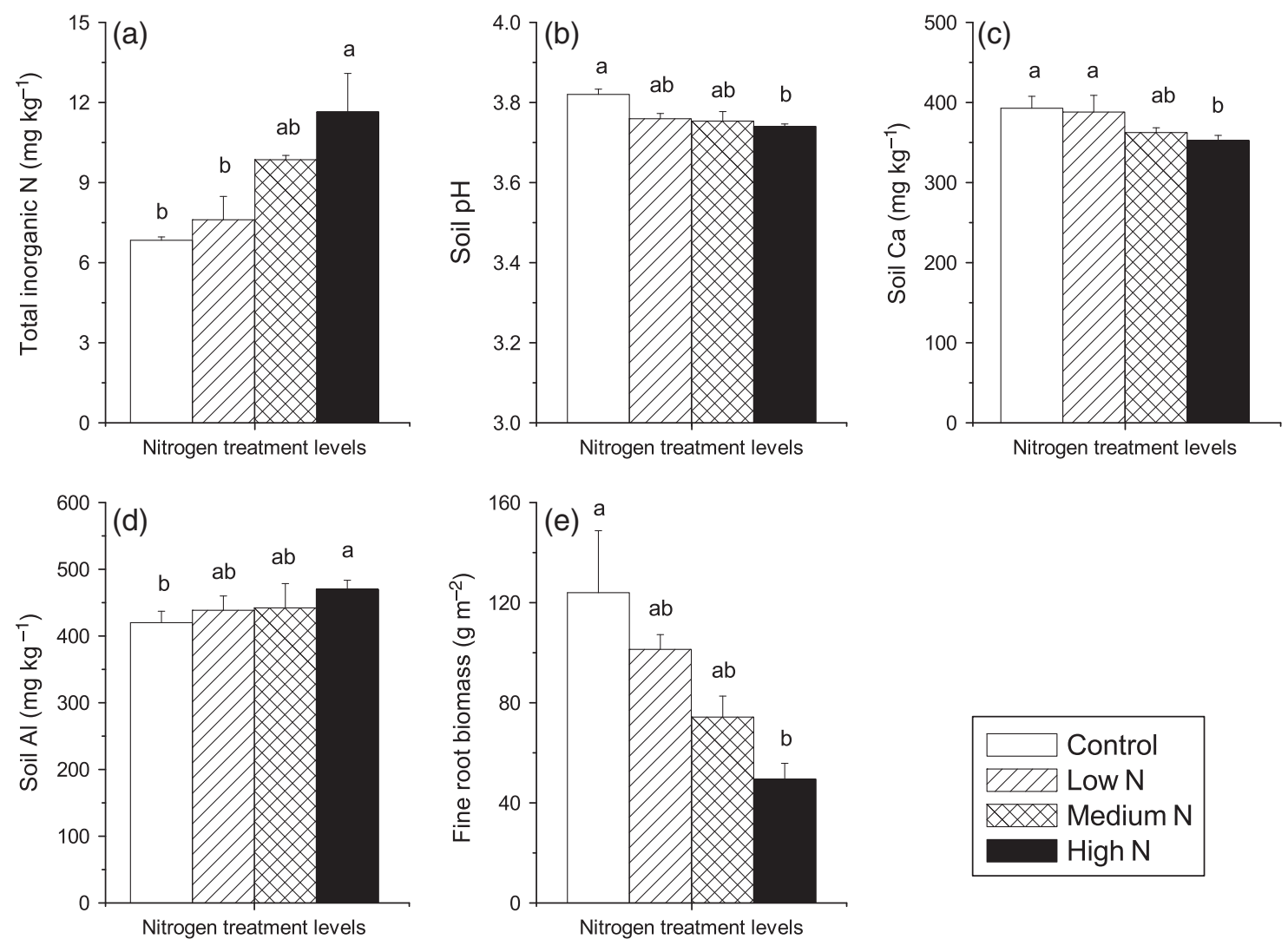

Fig. 6 Effects of different $\mathrm{N}$ treatment levels on soil chemical properties (a, total inorganic $\mathrm{N}$, the sum of $\mathrm{NH}_{4}^{+}-\mathrm{N}^{2}$ and $\mathrm{NO}_{3}^{-}-\mathrm{N}$; b, soil $\mathrm{pH}$; c, soil Ca; d, soil Al) and fine root biomass (e). Bars indicate $\pm \mathrm{SE}$. Bars with the same letter(s) are not significantly different at $P<0.05$ level among each $\mathrm{N}$ treatment by Tukey's honestly significantly different (HSD) test.

ditions, competing successfully growing in soil with low-N availability (Aerts \& Chapin, 2000). The shift from $\mathrm{N}$ limitation to $\mathrm{N}$ saturation in those ecosystems experiencing elevated $\mathrm{N}$ deposition, however, is accompanied both by increases in the availability of $\mathrm{N}$ in the soil and by decreases in spatial heterogeneity of $\mathrm{N}$ processing, potentially reducing coexistence of greater numbers of species through enhancing competitive exclusion by fast-growing nitrophilous plants (Aerts \& Chapin, 2000; Gilliam, 2006; Bobbink et al., 2010), and eventually decreasing plant diversity. Bobbink et al. (1998) summarized the effects of $\mathrm{N}$ deposition on plant communities throughout Europe and North America. They found that $\mathrm{N}$ deposition may have shifted plant communities towards species composition typical of high-N availability. This shift has often been associated with a loss in diversity of plant species, particularly in areas with high deposition rates. In a boreal forest of Sweden, the dominant species, Vaccinium myrtillus (an $\mathrm{N}$-efficient, ericaceous dwarf shrub), decreased significantly in density from increased $\mathrm{N}$ input, but Deschampsia flexuosa (a high $\mathrm{N}$-requiring grass) showed a positive response to increased $\mathrm{N}$ input (Strengbom et al., 2002, 2003).

Increases in $\mathrm{N}$ availability simultaneously minimize belowground competition for $\mathrm{N}$ and intensify aboveground competition for light, conferring a competitive advantage to functional groups with high leaf area (Suding et al., 2005, and references therein). Working in hardwood forests of North America, Hurd et al. (1998) found that cover of prominent herbaceous species declined significantly after only 3 years of $\mathrm{N}$ treatment; ferns species increased in cover, which likely lead to the decline in herb cover by increasing shading (George \& Bazzaz, 2003).

It is notable that these mechanisms were based largely on observations in $\mathrm{N}$-limited ecosystems to explain plant diversity changes in temperate and boreal forests and herb-dominated ecosystems, as found by Suding et al. (2005) in a meta-analysis of the responses of over 900 plant species in $34 \mathrm{~N}$-fertilization experiments carried out in herb-dominated ecosystems throughout the USA. In contrast, our study site was an undisturbed lowland tropical forest, protected from direct human 
land use disturbance for more than 400 years (Shen et al., 1999) which has become $\mathrm{N}$ saturated from both chronic high-N deposition in the region and the age of the ecosystem (Mo et al., 2006, 2008b). Accordingly, plant species of this forest may be adapted to this kind of N-rich environment, and plant competition for $\mathrm{N}$ should be minimal. Thus, the competitive exclusion by rapidly growing, nitrophilous plants under elevated $\mathrm{N}$ deposition may not develop. Our results are consistent with this notion in that no plant grew rapidly in response to any level of $\mathrm{N}$ addition in all measured valuables (Figs 3-5, and Table 2; and plant height, data not shown), despite that fact that inorganic $\mathrm{N}$ (extractable $\mathrm{NH}_{4}^{+}+\mathrm{NO}_{3}^{-}$) essentially doubled from Control to High-N treatments (Fig. 6a). In fact, we observed two patterns of response among the five functional groups: plant diversity either showed no significant change, or showed significant declines (Table 2). We also found no significant differences among treatment plots in canopy closure (Fig. 2). Thus, it is unlikely that aboveground competition between understory plants for light was a factor to decrease plant diversity.

We suggest that reductions of plant diversity after high-N additions in our studied forest are largely related to changes in soil properties. It has been shown that elevated $\mathrm{N}$ inputs can lead to soil acidification (Matson et al., 1999), which will negatively affect plant growth. Our results support this observation, with soil $\mathrm{pH}$ decreasing greatly with increasing $\mathrm{N}$ additions (Fig. 6b). Low $\mathrm{pH}$ values in the higher $\mathrm{N}$-treated plots suggests a possible negative effect of $\mathrm{N}$ addition on plant growth, as Nakaji et al. (2001) reported that dry matter production of seedlings can be significantly reduced by low soil $\mathrm{pH}$ value. In a forest nursery experiment near our site, Mo et al. (2008a) found similar negative effects, as well as a reduction in seedling survival rate when soil $\mathrm{pH}$ declined to 4.7.

High- $\mathrm{N}$ additions can also lead to Al mobilization, which may be toxic to plant roots. Results from many studies in forest ecosystems have related $\mathrm{Al}$ mobility to toxic effects on plants, particularly in decreasing fine root biomass (Cronan et al., 1989; Nygaard \& de Wit, 2004). Our results showed that high-N addition simultaneously increased $\mathrm{Al}$ mobility and decreased fine root biomass (Fig. $6 \mathrm{~d}$ and e), which suggests that decreased fine root biomass at high-N addition may be related to the increased $\mathrm{Al}$ mobility. In a seedling experiment in an adjacent region, Zhou \& Norio (1995) found that fine roots were very sensitive to high $\mathrm{Al}$ concentration, and fine root biomass was lowest when soil soluble $\mathrm{Al}$ concentration was highest.

$\mathrm{N}$-mediated leaching of nutrient cations (e.g., Ca or $\mathrm{Mg}$ ) may limit plant growth. Our results suggest a negative response of soil $\mathrm{Ca}$ to increasing level of $\mathrm{N}$ addition (Fig. 6c). Leaching of essential nutrients could lead to element imbalance in plants, negatively impacting plant growth (Cronan \& Grigal, 1995; Watmough \& Dillon, 2003; Bauer et al., 2004; May et al., 2005; Bowman et al., 2008).

Finally, results from samples collected in 2004 showed that there were no significant $(P>0.05)$ differences for soil properties (soil $\mathrm{pH}$, inorganic $\mathrm{N}$, extractable $\mathrm{Ca}$ and Al) among treatment plots; at the same time, total plant diversity did not showed significant responses to $\mathrm{N}$ additions either. However, in 2005 (after 2 years of $\mathrm{N}$ applications), there appeared significant effects for fine root biomass (decrease), soil $\mathrm{pH}$ (decrease), inorganic $\mathrm{N}$ (increase), extractable Ca (decrease), and extractable $\mathrm{Al}$ (increase) under $\mathrm{N}$-treatment plots; meanwhile, total plant diversity decreased significantly in $\mathrm{N}$-treatment plots (especially in high-N addition plots). It has been shown that soil acidification can develop progressively during the $\mathrm{N}$ treatments, accompanied by an increase in exchangeable $\mathrm{Al}^{3+}$ and leaching losses of base cations (e.g., $\mathrm{Ca}^{2+}$ and $\mathrm{Mg}^{2+}$ ) (Matson et al., 1999; Jönsson et al., 2003; Högberg et al., 2006). Considering no significant difference in canopy closure between treatments (see Fig. 2), we believe that the decrease of diversity may be caused by $\mathrm{N}$-mediated chemical changes in soil.

These three mechanisms - increased acidification, increased $\mathrm{Al}$ mobility, and decreased base cation fertility - can also explain why the low-N addition $\left(50 \mathrm{~kg} \mathrm{Nha}^{-1} \mathrm{yr}^{-1}\right)$ treatment did not significantly change the plant diversity after 5 years of $\mathrm{N}$ additions. It is likely that the low-N additions in our study site did not significantly alter soil properties during the study period, despite that our rate of low- $\mathrm{N}$ additions was higher than the $20 \mathrm{~kg} \mathrm{Nha}^{-1} \mathrm{yr}^{-1}$ threshold for established for $\mathrm{N}$-deposition effects on understory plant diversity in temperate and boreal forests (Bobbink et al., 2010).

In conclusion, we have three important findings from this study: (1) high levels of $\mathrm{N}$ additions decreased plant diversity in this forest, a response seen primarily in tree seedling and fern functional groups; (2) the declines of diversity appeared to arise from $\mathrm{N}$-related changes in soil properties (e.g., significant decreases in $\mathrm{pH}$ and extractable $\mathrm{Ca}$, and increases in extractable $\mathrm{Al}$ ); (3) $\mathrm{N}$ additions did not lead to any increase in plant growth (no increase in all measured variables) in this $\mathrm{N}$-saturated tropical forest. Our first finding demonstrates the effect of excess $\mathrm{N}$ on the structure and function of tropical forest ecosystems. Community structure of tropical forests is dominated by trees in canopy and subcanopy layers. Seedlings of these tree species represented the dominant functional group in understory layer, comprising $\sim 50 \%$ of total species 
diversity. Accordingly, changes in species composition and richness of the tree seedling functional group may affect forest development (including community structure and composition) and affect ecosystem productivity and carbon sequestration, under elevated $\mathrm{N}$ deposition in the future. The second finding provides sharp contrast to competition-based mechanisms suggested in studies of understory communities in temperate and boreal forests (Bobbink et al., 1998, 2010; Strengbom et al., 2001; Gilliam, 2006, 2007). It may also suggest that $\mathrm{N}$-mediated declines in plant diversity of tropical forests may not be due to competition-based mechanisms, but rather to soil-related changes that are less conducive to plant growth and survival. Our third finding suggests that other nutrients (likely P) may be limiting to plant growth under $\mathrm{N}$-saturated conditions. It is well established that plant growth and production in tropical ecosystems is limited by $\mathrm{P}$ rather than N (e.g., Vitousek, 1984). Phosphorus limitation also can explain well the lack of positive response of plant biomass to $\mathrm{N}$ additions. This phenomenon was demonstrated by Bobbink \& Lamers (2002) in chalk grasslands of England and by Gress et al. (2007) in a mixed hardwood forest of eastern United States. Tian et al. (2009) synthesized $\mathrm{C}, \mathrm{N}$, and $\mathrm{P}$ data for over 5000 soils throughout China, finding that soils of the tropical and subtropical regions, which includes Dinghushan Forest, had the highest $\mathrm{C}: \mathrm{P}$ and $\mathrm{N}: \mathrm{P}$ ratios of all five climatic zones. Thus, $\mathrm{P}$ limitation may represent an additional factor explaining the response of the understory stratum to excess $\mathrm{N}$ in tropical forests. In addition, we intend to pursue further work in this area where we do look at plant nutrient elements (especially for $\mathrm{N}$ and $\mathrm{P}$ ).

\section{Acknowledgements}

This study was founded by Key Project of Chinese Academy of Sciences Knowledge Innovation Program (KZCX2-YW-432-2), and National Natural Science Foundation of China (No. 30970521, 40730102, 30900202). We wish to thank Dejun Li, Xiaoming Fang, Youchang Zhang, Dingsheng Mo, Yujia Huang, Lei Liu and Jurong Long for their skilful assistance in field work, Qingfa Yu for his assistance in laboratory work, and Dr. Sandra Brwon, Dr. Per Gundersen, Yongfei Bai, Weixing Zhu, Deqiang Zhang, Zhi'an Li and two anonymous reviewers for invaluable suggestions in this paper.

\section{References}

Aber JD, Goodale CL, Ollinger SV et al. (2003) Is nitrogen deposition altering the nitrogen status of Northeastern forests? Bioscience, 53, 375-389.

Aerts R, Chapin FS (2000) Mineral nutrition of wild plants revisited: a re-evaluation of processes and patterns. Advances in Ecological Research, 30, 1-67.

Bauer GA, Bazzaz FA, Minocha R et al. (2004) Effects of chronic N additions on tissue chemistry, photosynthetic capacity, and carbon sequestration potential of a red pine
(Pinus resinosa Ait.) stand in the NE United States. Forest Ecology and Management, 196, 173-186.

Bobbink R, Hicks K, Galloway J et al. (2010) Global assessment of nitrogen deposition effects on terrestrial plant diversity: a synthesis. Ecological Applications, 20, in press.

Bobbink R, Hornung M, Roelofs JGM (1998) The effects of air-borne nitrogen pollutants on species diversity in natural and semi-natural European vegetation. Journal of Ecology, 86, 717-738.

Bobbink R, Lamers LPM (2002) Effects of increased nitrogen deposition. In: Air Pollution and Plant Life, 2nd edn (eds Bell JNB, Treshow M), pp. 201-235. John Wiley and Sons, Ltd., Chichester, UK.

Bowman WD, Cleveland CC, Halada Å, Hreško J, Baron JS (2008) Negative impact of nitrogen deposition on soil buffering capacity. Nature Geoscience, 1, 767-770.

Brunet J, Diekmann M, Falkengren-Grerup U (1998) Effects of nitrogen deposition on field layer vegetation in south Swedish forests. Environmental Pollution, 102, 35-40.

Cao HL, Huang ZL, Zhang LY, Kong GH (2002) Vegetation map of Dinghushan nature reserve. In: Tropical and Subtropical Forest Ecosystem, Vol. 9 (ed. Dinghushan Forest Ecosystem Research Station pp. 1-9. China Environmental Science Press, Beijing (in Chinese with English abstract).

Carfrae JA, Skene KR, Sheppard LJ, Ingleby K, Crossley A (2006) Effects of nitrogen with and without acidified sulphur on an ectomycorrhizal community in a Sitka spruce (Picea sitchensis Bong. Carr) forest. Environmental Pollution, 141, 131-138.

Clark CM, Tilman D (2008) Loss of plant species after chronic low-level nitrogen deposition to prairie grasslands. Nature, 451, 712-715.

Coomes DA, Allen RB, Bentley WA et al. (2005) The hare, the tortoise and the crocodile: the ecology of angiosperm dominance, conifer persistence and fern filtering. Journal of Ecology, 93, 918-935.

Cronan CS, April RH, Bartlett RJ et al. (1989) Aluminum toxicity in forests exposed to acidic deposition: the ALBIOS results. Water, Air, and Soil Pollution, 48, 181-192.

Cronan CS, Grigal DF (1995) Use of calcium/aluminum ratios as indicators of stress in forest ecosystems. Journal of Environmental Quality, 24, 209-226.

Dirkse GM, Van Dobben HF, Tamm CO (1991) Effects of fertilization on herb and moss layers of a Scots pine stand in Lisselbo (Sweden): a multivariate analysis. Report 91/7. Research Institute for Nature Management, Leersum, the Netherlands.

Fang Y, Gundersen P, Mo J, Zhu W (2009) Nitrogen leaching in response to increased nitrogen inputs in subtropical monsoon forests in southern China. Forest Ecology and Management, 257, 332-342.

Fang YT, Gundersen P, Mo JM, Zhu WX (2008) Input and output of dissolved organic and inorganic nitrogen in subtropical forests of South China under high air pollution. Biogeosciences, 5, 339-352.

Frey SD, Knorr M, Parrent JL, Simpson RT (2004) Chronic nitrogen enrichment affects the structure and function of the soil microbial community in temperate hardwood and pine forests. Forest Ecology and Management, 196, 159-171.

Galloway JN, Aber JD, Erisman JW et al. (2003) The nitrogen cascade. BioScience, 53, 341-356.

Galloway JN, Townsend AR, Erisman JW et al. (2008) Transformation of the nitrogen cycle: recent trends, questions and potential solutions. Science, 320, 889-892.

George LO, Bazzaz FA (2003) The herbaceous layer as a filter determining spatial pattern in forest tree regeneration. In: The Herbaceous Layer in Forests of Eastern North America (eds Gilliam FS, Roberts MR), pp. 265-282. Oxford University Press, New York.

Gilliam FS (2006) Response of the herbaceous layer of forest ecosystems to excess nitrogen deposition. Journal of Ecology, 94, 1176-1191.

Gilliam FS (2007) The ecological significance of the herbaceous layer in forest ecosystems. BioScience, 57, 845-858.

Gilliam FS, Hockenberry AW, Adams MB (2006) Effects of atmospheric nitrogen deposition on the herbaceous layer of a central Appalachian hardwood forest. Journal of the Torrey Botanical Society, 133, 240-254.

Gilliam FS, Roberts MR (2003) Introduction: conceptual framework for studies of the herbaceous layer. In: The Herbaceous Layer in Forests of Eastern North America (eds Gilliam FS, Roberts MR), pp. 3-11. Oxford University Press, New York.

Gress SE, Nichols TD, Northcraft CC, Peterjohn WT. (2007) Nutrient limitation in soils exhibiting differing nitrogen availabilities: what lies beyond nitrogen saturation? Ecology, 88, 119-130.

Högberg P, Fan H, Quist M, Binkley D, Tamm CO (2006) Tree growth and soil acidification in response to 30 years of experimental nitrogen loading on boreal forest. Global Change Biology, 12, 489-499.

Holdridge LR (1967) Life Zone Ecology. Tropical Science Center, San Jose, Costa Rica.

Huang ZF, Fan ZG (1982) The climate of Dinghushan (in Chinese with English abstract). In: Tropical and Subtropical Forest Ecosystem, Vol. 1, pp. 11-23. Science Press, Beijing. 
Huang ZL, Ding MM, Zhang ZP, Yi WM (1994) The hydrological processes and nitrogen dynamics in a monsoon evergreen broad-leafed forest of Dinghushan. Acta Phytoecologica Sinica, 18, 194-199 (in Chinese with English abstract).

Hurd TM, Brach AR, Raynal DJ (1998) Response of understory vegetation of Adirondack forests to nitrogen additions. Canadian Journal of Forest Research, 28, 799-807.

Jönsson U, Rosengren U, Thelin G, Nihlgård B (2003) Acidification-induced chemical changes in coniferous forest soils in southern Sweden 1988-1999. Environmental Pollution, 123, 75-83.

Lamarque JF, Kiehl JT., Brasseur GP et al. (2005) Assessing future nitrogen deposition and carbon cycle feedback using a multimodel approach: analysis of nitrogen deposition. Journal of Geophysical Research, 110, D19303, doi: 10.1029/2005JD005825.

Lambin EF, Geist HJ (2006) Land-Use and Land-Cover Change: Local Processes and Global Impacts (Global Change-The IGBP Series). Springer-Verlag, Berlin, Heidelberg.

Li Y, Zhang B, Qin S, Li S, Huang X (2008) Review of research and application of forest canopy closure and its measuring methods. World Forestry Research, 21, 40-46 (in Chinese with English abstract).

Lu X, Mo J, Dong S (2008) Effects of nitrogen deposition on forest biodiversity. Acta Ecologica Sinica, 28, 5532-5548.

Lu XK, Mo JM, Gundersen P et al. (2009) Effect of simulated N deposition on soil exchangeable cations in three forest types of subtropical China. Pedosphere, 19, 189-198.

Ma XH (1989) Effects of rainfall on the nutrient cycling in man-made forests of Cunninghamia lanceolata and Pinus massoniana. Acta Ecologica Sinica, 9, 15-20 (in Chinese with English abstract).

MacDonald JA, Dise NB, Matzner E, Armbruster M, Gundersen P, Forsius M (2002) Nitrogen input together with ecosystem nitrogen enrichment predict nitrate leaching from European forests. Global Change Biology, 8, 1028-1033.

Machado J-L, Reich PB (1999) Evaluation of several measures of canopy openness as predictors of photosynthetic photon flux density in deeply shaded conifer-dominated forest understory. Canadian Journal of Forest Research, 29, 1438-1444.

Magill AH, Aber JD, Currie WS et al. (2004) Ecosystem response to 15 years of chronic nitrogen additions at the Harvard Forest LTER, Massachusetts, USA. Forest Ecology and Management, 196, 7-28.

Matson PA, McDowell WH, Townsend AR, Vitousek PM (1999) The globalization of N deposition: ecosystem consequences in tropical environments. Biogeochemistry, 46, $67-83$

May JD, Burdette E, Gilliam FS, Adams MB (2005) Interspecific divergence in foliar nutrient dynamics and stem growth in a temperate forest in response to chronic nitrogen inputs. Canadian Journal of Forest Research, 35, 1023-1030.

Mo JM, Brown S, Peng SL, Kong GH (2003) Nitrogen availability in disturbed, rehabilitated and mature forests of tropical China. Forest Ecology and Management, 175, 573-583

Mo JM, Brown S, Xue JH, Fang YT, Li ZA (2006) Response of litter decomposition to simulated $\mathrm{N}$ deposition in disturbed, rehabilitated and mature forests in subtropical China. Plant and Soil, 282, 135-151.

Mo JM, Li D, Gundersen P (2008a) Seedling growth response of two tropical tree species to nitrogen deposition in southern China. European Journal of Forest Research, 127, 275-283.

Mo JM, Zhang W, Zhu WX et al. (2008b) Nitrogen addition reduces soil respiration in a mature tropical forest in southern China. Global Change Biology, 14, 403-412.

Nakaji T, Fukami M, Dokiya Y, Izuta T (2001) Effects of high nitrogen load on growth, photosynthesis and nutrient status of Cryptomeria japonica and Pinus densiflra seedlings. Trees, 15, 453-461.

Nordin A, Strengbom J, Ericson L (2006) Responses to ammonium and nitrate additions by boreal plants and their natural enemies. Environmental Pollution, 41, 167-174

Nygaard PH, de Wit HA (2004) Effects of elevated soil solution Al concentrations on fine roots in a middle-aged Norway spruce (Picea abies (L.) Karst.) stand. Plant and Soil, 265, 131-140.

Phoenix GK, Hicks WK, Cinderby S et al. (2006) Atmospheric nitrogen deposition in world biodiversity hotspots: the need for a greater global perspective in assessing $\mathrm{N}$ deposition impacts. Global Change Biology, 12, 470-476.

Rainey SM, Nadelhoffer KJ, Silver WL, Downs MR (1999) Effects of chronic nitrogen additions on understory species abundance and nutrient content in a red pine plantation. Ecological Applications, 9, 949-957.

Reidsma P, Tekelenburg T, van den Berg M, Alkemade R (2006) Impacts of land-use change on biodiversity: an assessment of agricultural biodiversity in the European Union. Agriculture, Ecosystems and Environment, 114, 86-102.
Ren R, Mi FJ, Bai NB (2000) A chemometrics analysis on the data of precipitation chemistry of China. Journal of Beijing Polytechnic University, 26, $90-95$ (in Chinese with English abstract).

Rosenzweig ML (1995) Species Diversity in Space and Time. Cambridge University Press, Cambridge, UK.

Sala OE, Chapin FS III, Armesto JJ et al. (2000) Global biodiversity scenarios for the year 2100. Science, 287, 1770-1774.

Shen CD, Liu TS, Peng SL et al. (1999) ${ }^{14} \mathrm{C}$ measurement of forest soils in Dinghushan Biosphere Reserve. Chinese Science Bulletin, 44, 251-256.

Sotta ED, Corre MD, Veldkamp E (2008) Differing N status and N retention processes of soils under old-growth lowland forest in Eastern Amazonia, Caxiuanã, Brazil. Soil Biology \& Biochemistry, 40, 740-750.

Stevens CJ, Dise NB, Mountford JO, Gowing DJ (2004) Impact of nitrogen deposition on the species richness of grasslands. Science, 303, 1876-1879.

Strengbom J, Nordin A, Näsholm T, Ericson L (2001) Slow recovery of boreal forest ecosystem following decreased nitrogen input. Functional Ecology, 15, 451457.

Strengbom J, Nordin A, Näsholm T, Ericson L (2002) Parasitic fungus mediates change in nitrogen-exposed boreal forest vegetation. Journal of Ecology, 90, 61-67.

Strengbom J, Walheim M, Näsholm T, Ericson L (2003) Regional differences in occurrences of understorey forest species reflect differences in $\mathrm{N}$ deposition. Ambio, 32, 91-97.

Suding KN, Collins SL, Gough L et al. (2005) Functional- and abundance-based mechanisms explain diversity loss due to $\mathrm{N}$ fertilization. Proceedings of the National Academy of Sciences USA, 102, 4387-4392.

Thomas CD, Cameron A, Green RE et al. (2004) Extinction risk from climate change. Nature, 427, 145-148.

Throop H, Lerdau MT (2004) Effects of nitrogen deposition on insect herbivory: implications for community and ecosystem processes. Ecosystems, 7, 109-133.

Thuiller W (2007) Biodiversity: climate change and the ecologist. Nature, 448, 550-552.

Tian H, Chen G, Zhang C, Melillo JM, Hall CAS (2009) Pattern and variation of C:N: $P$ ratios in China's soils: a synthesis of observational data. Biogeochemistry, in press doi: 10.1007/s10533-009-9382-0.

van Dobben HF, ter Braak CJF, Dirkse GM (1999) Undergrowth as a biomonitor for deposition of nitrogen and acidity in pine forest. Forest Ecology and Management, 114, 83-95.

Vitousek PM (1984) Litterfall, nutrient cycling, and nutrient limitation in tropical forests. Ecology, 65, 285-298.

Vitousek PM, Aber JD, Howarth RW et al. (1997) Human alteration of the global nitrogen cycle: sources and consequences. Ecological Applications, 7, 737-750.

Vitousek PM, Howarth RW (1991) Nitrogen limitation on land and in the sea: how can it occur? Biogeochemistry, 13, 87-115.

Wallace ZP, Lovett GM, Hart JE, Machona B (2007) Effects of nitrogen saturation on tree growth and death in a mixed-oak forest. Forest Ecology and Management, 243, 210-218.

Watmough SA, Dillon PJ (2003) Base cation and nitrogen budgets for seven forested catchments in central Ontario, 1983-1999. Forest Ecology and Management, 177, 155177.

Wiegand T, Gunatilleke CV, Gunatilleke IA, Huth A (2007) How individual species structure diversity in tropical forests. Proceedings of the National Academy of Sciences USA, 104, 19029-19033.

Wilson EO (1988) The current state of biological diversity. In: Biodiversity (ed. Wilson EO), pp. 3-18. National Academy Press, Washington, DC.

Xu GL, Mo JM, Zhou GY, Fu SL (2006) Preliminary response of soil fauna to simulated $\mathrm{N}$ deposition in three typical subtropical forests. Pedosphere, 16, 596-601.

Xu YG, Zhou GY, Luo TS, Wu ZM, He ZC (2001) Soil solution chemistry and element budget in the forest ecosystem in Guangzhou. Acta Ecologica Sinica, 21, 1670-1681 (in Chinese with English abstract).

Zheng X, Fu C, Xu X et al. (2002) The Asian nitrogen cycle case study. Ambio, 31, 79-87.

Zhou GY, Norio O (1995) Effects of soil solutions leached by simulated acid rains on the growth of Pinus massonian and P. armandh seedlings. Chinese Journal of Applied Environmental Biology, 1, 136-144.

Zhou GY, Yan JH (2001) The influences of regional atmospheric precipitation characteristics and its element inputs on the existence and development of Dinghushan forest ecosystems. Acta Ecologica Sinica, 21, 2002-2012 (in Chinese with English abstract).

Zhou Z, Sun OJ, Huang J, Gao Y, Han X (2006) Land-use affects the relationship between species diversity and productivity at the local scale in a semi-arid steppe ecosystem. Functional Ecology, 20, 753-762. 


\section{Supporting Information}

Additional Supporting Information may be found in the online version of this article:

Appendix S1. A complete species list of the understory layer during the whole studied period from year 2003 to 2008, including Latin name, common name, family, and functional group to which plants belong.

Please note: Wiley-Blackwell are not responsible for the content or functionality of any supporting materials supplied by the authors. Any queries (other than missing material) should be directed to the corresponding author for the article. 